\title{
EDITORIAL
}

\section{Pursuing Transnational Policy Change}

\section{THE CHALLENGE OF TRANSNATIONAL POLICY CHANGE}

Environmental problems do not respect national boundaries, and efforts to resolve those problems often collide with the tragedy of the commons. ${ }^{1}$ Once scientific knowledge has helped to set the agenda by identifying potential environmental risks, substantial barriers to cooperation must be overcome, including divergent interests among the relevant actors, the need for political support in multiple jurisdictions, the potential for free riding, and the normal difficulties of coordinating the actions of multiple entities. Indeed, as Bodansky says, the 'obstacles to international cooperation present a picture that is so daunting that it is hard to conceive how international environmental cooperation has ever emerged'. ${ }^{2}$ Yet, cooperation has been forthcoming in a number of contexts, both between national governments through international law and through alternative transnational mechanisms.

Environmental problems remain pressing, and a key issue for study is how cooperative action to address a problem comes into existence. At least equally important is the question of how existing cooperative efforts can be strengthened to deal more adequately with environmental risks. This is no easy task even in the setting of domestic regulation in developed countries. It is exponentially more difficult in a context of multi-jurisdictional problems and in a world that includes countries at all stages of economic and political development.

The articles in this issue, while diverse in their subject matter, share a common theme: the problem of identifying ways of changing policy in a complex and often resistant governance system. ${ }^{3}$ As a new departure for $T E L$, some of the articles also feature replies and rejoinders that allow for scholarly discussions to form and probe issues in greater depth. Taken as a whole, the articles and commentaries in this issue

1 D. Bodansky, The Art and Craft of International Environmental Law (Harvard University Press, 2010), at p. 52 .

2 Ibid., at p. 145.

3 Two helpful attempts to understand functional and design issues in transnational environmental law are K. O'Neill, The Environment and International Relations (Cambridge University Press, 2011), and Bodansky, n. 1 above. An effort relating to international law more generally is A.T. Guzman, How International Law Works: A Rational Choice Theory (Oxford University Press, 2008). 
make measurable progress towards the goal of understanding how to strengthen the system of transnational environmental law and governance.

We begin by considering the traditional domain of international environmental law: legal relations between national sovereigns. Within that domain, articles examine issues relating to treaties, customary law, and international dispute resolution. We then consider approaches set in the expanding scope of transnational environmental law, including subnational and supranational governments and the role of non-governmental entities.

\section{THE TOOLS OF INTERNATIONAL ENVIRONMENTAL LAW}

A logical order for the discussion of international environmental law would be to begin with the sources of law (treaties, customary law, soft law) and then turn to dispute resolution and compliance. However, the structure of the individual articles and responses would make that ordering confusing, so we address the topics in a different order: beginning with international litigation, then turning to sources of law.

In the domestic context, lawyers may often think of litigation (or at least the threat of litigation) as the means of settling disputes. In the context of international environmental law, formal dispute resolution has played a less central role. Nevertheless, it may sometimes be the best recourse in dealing with an otherwise recalcitrant dispute.

Sean Stephenson, Arne Mooers and Amir Attaran argue that the conflict over protection of small cetaceans is one such recalcitrant conflict justifying recourse to litigation. ${ }^{4}$ As they explain, the International Whaling Commission (IWC) has long been mired in a controversy over whether it has jurisdiction over small cetaceans, such as dolphins. Stephenson, Mooers and Attaran argue that the IWC does have the authority to protect small cetaceans and that the commercial taking of small cetaceans violates the moratorium on commercial whaling. They provide a variety of legal and scientific arguments for this interpretation of the International Convention for the Regulation of Whaling (ICRW). ${ }^{5}$ In their view, litigation in the International Court of Justice (ICJ) is the best way to move forward because international negotiations have been at an impasse for many decades.

Stephenson and his colleagues observe that despite efforts to bring small cetaceans within the ICRW, the lack of any consensus on the issue has meant, in practice, that the 1982 moratorium on commercial whaling applies only to large whales. Underlying the lack of consensus is in large part the resistance of Japan, which was unwillingly made a party to the ICRW during the post-World War II occupation and seemingly has been rebelling against the Convention's restrictions ever since. Indeed, there is some evidence that Japan has made use of improper inducements to

\footnotetext{
4 S. Stephenson, A. Mooers \& A. Attaran, 'Does Size Matter? The ICRW and the Inclusion of Small Cetaceans' (2014) 3(2) Transnational Environmental Law, pp. 241-63.

5 Washington, DC (US), 2 Dec. 1946, in force 10 Nov. 1948, available at: http://iwc.int/convention.
} 
recruit the support of other countries to its positions, perhaps including bribery. The net result has been a singular lack of progress.

Stephenson, Mooers and Attaran call for a judicial resolution of the coverage issue. The recent ICJ decision on another whaling issue, in Australia v. Japan, ${ }^{6}$ gives them hope that the Court would be willing to decide this issue, and they explore several possible procedural mechanisms for bringing the matter before the ICJ. Stephenson and his co-authors argue that the most promising of these procedural mechanisms seems to be a request for an advisory opinion by the United Nations (UN) Food and Agriculture Organization (FAO) or the UN General Assembly (UNGA).

In terms of the merits of the issue, the authors point out that the size distinction is scientifically irrelevant: small cetaceans belong to the sub-order of toothed whales within the order of all whales. The same zoological family that contains dolphins includes orcas, which are covered by the treaty, but, as they concede, science is not necessarily determinative of the interpretation of the treaty.

In a response to this argument for ICJ intervention, Ed Couzens argues in favour of diplomacy, rather than litigation, as the most effective approach. ${ }^{7}$ Couzens suggests two routes for progress that he considers promising. The first is the 'Future of the IWC' compromise process. The other is a recent resolution by Monaco that advocated involving the UNGA in the issue.

In their rejoinder, Stephenson, Mooers and Attaran re-emphasize the evidence that the IWC process is broken. ${ }^{8}$ They view the bitterness and stalled negotiations within the IWC as arguing for a shift to a forum in which more rational discussion of the relevant science and law would be possible. The rejoinder also suggests, as an analogy to the problem, that it would be absurd to interpret a provision about 'dogs' to exclude Chihuahuas because of their small size. ${ }^{9}$ Yet, this may not be as simple an argument as the authors suggest: one would be hesitant to construct a reference to 'cats' to include tigers, even though technically (as they themselves point out) both tigers and domestic cats are types of cat. It also seems possible that, even if the IWC itself is capable of being extended to small cetaceans, the whaling moratorium might be construed differently in light of its own purpose and drafting history. Although the issue may be more complex, Stephenson and his colleagues clearly raise some formidable points for their side of the argument.

Their proposal to resort to the ICJ is something of a departure, given that 'traditional dispute settlement still plays a negligible role in the implementation of international environmental law'. ${ }^{10}$ However, as international environmental law matures, and as tribunals become more familiar with the area, recourse to international dispute

6 ICJ, Whaling in the Antarctic (Australia v. Japan; New Zealand intervening), Judgment of 31 Mar. 2014, available at: http://icj-cij.org/docket/files/148/18136.pdf (holding that Japan's purported scientific whaling programme was not credibly covered by the scientific whaling provision of the moratorium).

7 E. Couzens, 'Size Matters, Although It Shouldn't: The ICRW and Small Cetaceans. A Reply to Stephenson, Mooers and Attaran' (2014) 3(2) Transnational Environmental Law, pp. 265-78.

8 S. Stephenson, A. Mooers \& A. Attaran, 'A Rejoinder to “Size Matters, Although It Shouldn't: The ICRW and Small Cetaceans”' (2014) 3(2) Transnational Environmental Law, pp. 279-83.

9 Ibid, at p. 280.

10 Bodansky, n. 1, above, at p. 247. 
resolution seems likely to become more frequent. For those seeking to break roadblocks in reaching international agreement, litigation may be an increasingly appealing step towards fostering environmental policy change.

Litigation may not always be successful, however, and an important question relates to how to make further progress through other mechanisms after unsuccessful litigation. In their contribution to this issue, Howard Schiffman and Briony MacPhee examine the aftermath of the 1990 s Southern Bluefin Tuna dispute. ${ }^{11}$ In well-known decisions, the International Tribunal for the Law of the Sea (ITLOS) granted provisional measures to halt a unilateral Japanese experimental fishing programme, followed by an arbitral panel decision that the dispute arose solely under the Convention on the Conservation of Southern Bluefin Tuna (SBT Convention). ${ }^{12}$ In their commentary, Schiffman and MacPhee explore the legacy of that dispute with particular emphasis on the growth and development of the Commission for the Conservation of Southern Bluefin Tuna (CCSBT) and how the regime is functioning with the addition of several new members. International fisheries are a classic example of the tragedy of the commons, presenting tough governance issues. ${ }^{13}$ Schiffman and McPhee probe the challenges of managing this fish stock and suggest several promising policy alternatives.

The tuna stock has done poorly since the decision, with a consequent decline in national catch limits, but it may have sparked some progress on the governance front. The CCSBT has expanded from its original troika of Japan, Australia and New Zealand with the addition of other nations exploiting the fishery, which may have helped to address the polarization between the original three. In addition, the Commission has added an Advisory Panel of non-Member States with general expertise in fisheries, in order to provide a source of objective advice. Despite these governance changes, the conservation status of the tuna remains precarious. Schiffman and MacPhee suggest the possibility of bypassing the SBT Convention and invoking the Convention on International Trade in Endangered Species of Wild Fauna and Flora (CITES). ${ }^{14}$

An alternative analytic approach might shed further light on the situation. Economist Gary Libecap has suggested that the effectiveness of international environmental measures depends on four factors: scientific uncertainty, the presence of distributional issues, asymmetric information, and the extent of compliance and new entry. ${ }^{15}$ He has applied this theory with respect to another tuna stock (the Atlantic bluefin tuna). Despite management since 1969, the Atlantic bluefin tuna is currently the most vulnerable species of tuna. Libecap attributes this to scientific uncertainty, disparate interests of developing and developed countries, ease of entry into the fishery, and

11 H.S. Schiffman \& B.P. MacPhee, 'The Southern Bluefin Tuna Dispute Revisited: How Far Have We Come?' (2014) 3(2) Transnational Environmental Law, pp. 391-406.

12 Canberra (Australia), 10 May 1993, in force 20 May 1994 (SBT Convention), available at: http://www.ccsbt. org/userfiles/file/docs_english/basic_documents/convention.pdf.

13 Bodansky, n. 1 above, at p. 52.

14 Washington, DC (US), 3 Mar. 1973, in force 1 July 1975, available at: http://www.cites.org/eng/disc/ text.php.

15 G.D. Libecap, 'Addressing Global Environmental Externalities: Transaction Costs Considerations' (2014) 2 Journal of Economic Literature, pp. 424-79, doi:10.1257/jel.52.2.424. 
asymmetric information between fishing fleets and regulators. Notably, in 2010, a proposal to list the species under CITES failed because of opposition from developing countries. On the other hand, he says, these problems are less acute for the Western \& Central Pacific Fisheries (WCPFC), which has had more effective management as a result.

The analysis points up the need to consider more systematically the reasons why some international agreements are more effective than others, even when the subject matters seem roughly similar. It also suggests that in attempting to consider the impacts of tribunal decisions we need to take into account intrinsic factors that may be driving developments.

Despite the growing significance of other transnational mechanisms, it remains true that '[b]y far the most important way that the international community has sought to govern the global environment is through cooperation among nations and the creation of multilateral environmental agreements (MEAs), or regimes ${ }^{\text {,16 }}$ - bearing in mind that the 'international community' is essentially the collectivity of nation states.

As the bluefin tuna and small cetaceans examples indicate, negotiations can be protracted and frustrating. Gaining political support for international action can be difficult when the stakes are seen as purely ecological. One intriguing possibility in some cases may be to reframe the issues to boost their political salience. In this vein, Patricia Farnese's article in this issue argues for a fresh approach to ecological issues, focusing on potential impacts on zoonotic disease control. ${ }^{17}$

Farnese begins by highlighting the widespread recognition of the threat posed by emerging zoonotic diseases to human and animal health and the economy. ${ }^{18}$ She argues that connections between wildlife health, land-use change, and zoonotic diseases have not been adequately addressed. Efforts to protect wild areas have not been framed as public health measures, and states have not been required to evaluate the health impacts of land-use changes. To the extent that the issue has received any attention, it has focused only on diseases that pose known threats to humans or domesticated animals, but the looming threat of new emerging diseases has been overlooked. Farnese argues in favour of a preventative approach to address this issue.

In a response commentary to Farnese, Stuart Harrop argues that many issues besides zoonotic diseases are closely linked to conservation issues, including economic development, climate change, food security and food safety, the prevention of disease, and rural poverty. ${ }^{19}$ Harrop advocates a holistic approach to these issues.

16 O’Neill, n. 3 above, at p. 71.

17 P.L. Farnese, 'The Prevention Imperative: International Health and Environmental Governance Responses to Emerging Zoonotic Diseases' (2014) 3(2) Transnational Environmental Law, pp. 285-309.

18 For additional background on the problem of zoonotic diseases, see T. Wanjura, 'International Standards for Managing Emerging and Re-Emerging Zoonoses of Public Health Significance: A Call for Horizontal Collaboration between Intergovernmental Organizations' (2007) 41(3) International Law, pp. 975-98.

19 S. Harrop, 'Holistic and Leadership Approaches to International Regulation: Confronting Nature Conservation and Developmental Challenges. A Reply to Farnese' (2014) 3(2) Transnational Environmental Law, pp. 311-20. 
In her rejoinder, Farnese agrees that a holistic approach makes theoretical sense, but she contends that it may be unmanageably broad in practice. ${ }^{20}$ She argues that there are powerful rhetorical and political advantages to be gained by reframing conservation issues as health issues.

A final mechanism for change in international environmental law is to establish new principles of customary international law. Ole Pedersen's contribution to this issue examines the debate over whether the precautionary principle is binding as customary international law. ${ }^{21}$ Using a recent arbitral decision involving the Indus River as a springboard for his analysis, ${ }^{22}$ Pedersen identifies two opposing camps in this debate and argues that, in reality, they use different methodologies. One camp relies primarily on state practice while the other relies on statements and declarations of rules. Pedersen concludes that there are multiple ways of identifying customary international rules.

The Indus dispute provides the starting point for Pedersen's discussion. The dispute centred on whether India had violated a 1960 treaty by diverting water from the river, whether the diversion was harmful, and how far India could bring down the level of a reservoir in connection with a large hydroelectric power project. ${ }^{23}$ Although a preliminary decision indicated a willingness to consider principles of current international environmental law, the final decision concluded that the treaty precluded recourse to such external sources of law, and it characterized the precautionary principle in terms indicating some doubts about its legally binding nature. ${ }^{24}$

The precautionary principle is doubtless familiar to readers of this journal. As Pedersen discusses, there is considerable controversy over whether the precautionary principle is a rule of customary international law. Supporters point to numerous examples in which international bodies or tribunals have articulated the principle, while opponents point to a dearth of clearly identifiable state practice motivated by a belief that actions are required by customary international law. ${ }^{25}$ In part, those who oppose according legal status to the precautionary principle argue that it is insufficiently clear cut to provide an operational legal norm. Pedersen argues persuasively that the precautionary principle is no more vague than recognized legal standards such as obligations of due diligence or good faith. Nevertheless, it is more difficult to determine the existence of a crystallized governmental practice when a rule is

20 P.L. Farnese, 'A Rejoinder to "Holistic and Leadership Approaches to International Regulation: Confronting Nature Conservation and Developmental Challenges" (2014) 3(2) Transnational Environmental Law, pp. 321-2.

21 O.W. Pedersen, 'From Abundance to Indeterminacy: The Precautionary Principle and Its Two Camps of Custom' (2014) 3(2) Transnational Environmental Law, pp. 323-39.

22 Permanent Court of Arbitration (PCA), In the Matter of the Indus Waters Kishenganga Arbitration (Islamic Republic of Pakistan v. Republic of India), Partial Award of 18 Feb. 2013, at paras 223-7, available at: http://www.pca-cpa.org/showpage.asp?pag_id=1392.

23 For background on the treaty and the dispute resolution mechanism, see T.E. Robins, 'Defusing Hydroelectric Brinkmanship: The Indus Waters Treaty's Alternate Dispute Resolution Provisions and Their Role in the Tenuous Peace between India and Pakistan' (2013) 5 Yearbook on Arbitration \& Mediation, pp. 389-408.

24 Pedersen, n. 21 above.

25 Ibid. 
flexible or broad. This is all the more so because, in the real world, clear-cut governmental endorsements of the precautionary principle, or explicit refusals to apply it, are likely to be scarce.

The broader question Pedersen raises is how to identify customary law. He points out that, despite the classical insistence on state practice, it is easy to find instances of tribunals or other authorities relying more on proclamations by states and international bodies rather than actual practice. ${ }^{26}$ Indeed, in practical terms, what is important may be less why states undertake actions than whether a view of custom results in reputational sanctions or adverse responses for actions inconsistent with the custom. $^{27}$ Thus, the question of how to establish the existence of customary law is itself disputed and may be partly context-dependent.

For present purposes, the most interesting implication relates to transnational legal change. Pedersen's article calls attention to the potential for change to occur through promoting soft-law resolutions such as the Rio Declaration, ${ }^{28}$ and then having them harden into recognition as customary international law.

Making progress in international environmental law has never been easy, and it is unlikely that it ever will be. It is difficult enough to persuade any one national government to adopt a new policy, let alone to persuade a group of nations to cohere on a policy. Yet, we are gradually gaining a better understanding of how to foster positive changes through the international legal system.

\section{BEYOND CLASSIC PUBLIC INTERNATIONAL LAW}

It is a familiar axiom that international environmental law operates largely as a system of law between states'. ${ }^{29}$ In this paradigm, each nation is envisioned as otherwise independent and self-enclosed. Transnational environmental law calls attention to the many other ways in which policy responds to outside influence, including the involvement of entities besides national governments. Policy can cross national boundaries in many ways, from interactions between non-governmental organizations (NGOs), or the influence of experts, to cooperation between subnational governments or interactions with supranational organizations. These transnational channels provide new opportunities for positive policy developments.

One such channel reaches across to private actors and civil society. In the classic vision of international law, private citizens have no role in shaping the law, but NGOs play an increasingly important part in shaping policy in the international, as well as the domestic, sphere. ${ }^{30}$

26 Ibid. For a survey of the conflicting theories of customary law, see Guzman, n. 3 above, at pp. 184-8.

27 Guzman, n. 3 above, at p. 202.

28 Declaration on Environment and Development, Rio de Janeiro (Brazil), 3-14 June 1992, available at: http://www.un.org/documents/ga/conf151/aconf15126-1annex1.htm.

29 Bodansky, n. 1 above, at p. 159.

30 O'Neill, n. 3 above, at pp. 89-92. However, Guzman (n. 3 above, at p. 29) points out that there are many other possible mechanisms including 'unilateral actions, repeated practice, informal or tacit agreements, third-party intervention, and so forth'. 
Even in the relatively inhospitable circumstances of today's Russia NGOs have gained some traction, as Ekaterina Sofronova, Cameron Holley and Vijaya Nagarajan show in their article in this issue. ${ }^{31}$ This is all the more surprising because of the low level of trust for civil society organizations in Russia, the small size of the NGO sector, and the lack of public familiarity with NGOs. ${ }^{32}$

Sofronova, Holley, and Nagarajan examine the activities of Russian NGOs, which are increasingly beset with government restrictions. Drawing on interviews with Russian and international NGOs, they conclude that NGOs still enjoy legitimacy, but are increasingly threatened. The authors propose several measures to strengthen Russian NGOs.

NGOs in Western countries tend to play roles in public mobilization and litigation. In the Russian setting, public mobilization is difficult (and sometimes dangerous) and litigation is often fruitless. But NGOs have nonetheless had some impact by providing input through governmental forums in policy formulation and, more surprisingly, by providing expertise and resources to natural resource agencies that are themselves starved of resources. ${ }^{33}$

From a transnational legal perspective, relationships between NGO activity across borders are particularly interesting. As Sofronova and her co-authors explain, Russian NGOs are divided into two classes: affiliates of international NGOs like Greenpeace, and smaller locally based NGOs that often rely on those foreign affiliates for support and expertise. Foreign affiliates may also provide access to methods of action outside Russia's borders. In at least one instance, a local NGO partnered with a foreign affiliate to bring a legal action outside Russia, sidestepping the limitations of the Russian legal system. $^{34}$

The Russian government is increasingly cracking down on NGOs that are supported by foreign organizations, although the focus seems to be more on cutting off foreign-based assistance to local Russian NGOs than on challenging the affiliates of international organizations. ${ }^{35}$ Given the purported purpose of limiting foreign influence in Russia, this approach is difficult to understand, but it makes sense when viewed as an effort to hinder the development of an independent grassroots civil society that might ultimately prove a focal point for challenging state authority. Thus, the government's measures threaten to pull the local NGOs away from foreign-derived support and make them more reliant on state funding (and thus, more subject to state control). ${ }^{36}$ Sofronova, Holley and Nagarajan explore possible responses to these threats, including partnering with businesses, and changes in state policy, such as easier access to state funding and expanded public access to information that would

31 E. Sofronova, C. Holley \& V. Nagarajan, 'Environmental Non-Governmental Organizations and Russian Environmental Governance: Accountability, Participation and Collaboration' (2014) 3(2) Transnational Environmental Law, pp. 341-71. Ibid.

33 Ibid.

34 Ibid.

35 Ibid.

36 Ibid. 
promote NGO participation. ${ }^{37}$ Note, however, that increased reliance on state funding also has the potential to threaten the independence of locally based NGOs.

\subsection{Beyond Sovereignty}

Transnational law involves a broader set of tools than traditional international law. ${ }^{38}$ It includes actions that span national boundaries by other actors such as NGOs as well as subnational and supranational governance institutions.

For instance, although their lack of sovereignty makes subnational units invisible to classical international law, they have become increasingly important in addressing transborder and even global environmental problems. ${ }^{39}$ The most prominent example is climate change, where subnational units such as American state governments have sometimes been at the forefront of efforts to control carbon emissions. ${ }^{40}$

Transnational law also encompasses the relationships between states and supranational organizations. Robert Baldwin, Julia Black and Gerard O'Leary provide an illuminating example of this form of legal influence in their article exploring the impact of European Union (EU) pressures on risk regulation in Ireland. ${ }^{41}$ They examine the process that led the Irish Environmental Protection Agency (EPA) to develop a National Inspection Plan for domestic waste water treatment systems such as septic tanks. Their discussion focuses on two issues: the role of transnational institutional settings in galvanizing innovation and regulatory reform, and the practical challenges of dealing with low-level risks. It should be noted that much of their discussion also bears on the general problem of controlling risks that might be quite severe cumulatively but that result from the behaviour of dispersed individuals, an issue of increasing importance in environmental regulation. ${ }^{42}$

The story began at the end of 2009, when the European Court of Justice (ECJ) ruled in European Commission v. Ireland ${ }^{43}$ that Ireland had defaulted on its obligation to implement Articles 4 and 8 of the EU Waste Framework Directive. ${ }^{44}$ As Baldwin, Black, and O'Leary point out, a follow-up case regarding the amount of the penalty happened

37 Ibid.

38 K.W. Abbott, 'Strengthening the Transnational Regime Complex for Climate Change' (2014) 3(1) Transnational Environmental Law, pp. 57-88; K.W. Abbott \& D. Snidal, 'Strengthening International Regulation through Transnational New Governance: Overcoming the Orchestration Deficit' (2009) 42(2) Vanderbilt Journal of Transnational Law pp. 501-78; T. Hale \& D. Held (eds), Handbook of Transnational Governance: Institutions \& Innovations (Polity Press, 2011).

39 See, e.g., D.A. Farber, 'Climate Policy and the United States System of Divided Powers: Dealing with Carbon Leakage and Regulatory Linkage' (2014) 3(1) Transnational Environmental Law, pp. 31-55; D.A. Farber, 'Issues of Scale in Climate Governance', in J.S. Dryzek, R.B. Norgaard \& D. Schlosberg (eds), The Oxford Handbook of Climate Change and Society (Oxford University Press, 2011). Ibid.

41 R. Baldwin, J. Black \& G. O’Leary, 'Risk Regulation and Transnationality: Institutional Accountability as a Driver of Innovation' (2014) 3(2) Transnational Environmental Law, pp. 373-90.

42 M.P. Vandenbergh, 'From Smokestack to SUV: The Individual as Regulated Entity in the New Era of Environmental Law' (2004) 57 Vanderbilt Law Review, pp. 515-628.

43 Case C-188/08 European Commission v Ireland [2009] ECR I-172.

44 Directive 75/442/EEC of 15 July 1975 on Waste [1975] OJ L 194/39, last amended by Directive 2008/98/EC of 19 November 2008 on Waste [2008] OJ L 312/3. 
to coincide with the bail-out of Ireland following the financial crisis by the troika of the World Bank, the International Monetary Fund (IMF) and the European Commission. The bail-out itself contained a provision relating to water services calling for charges for water services. The effect of this coincidence in timing was to make the ECJ ruling far more politically salient than it would otherwise have been. ${ }^{45}$

The authors are able to provide unusual insights into what happened next because they were direct participants. Baldwin and Black had created a model for regulating low-level risks for a cross-agency research body. This model provided a roadmap for dealing with low-level risks by categorizing compliance difficulties and enforcement priorities. Thus, by adopting the model, Ireland was not only crafting a particular regulation but also accepting a framework for use in dealing with other types of low-level risk. Because there were half a million septic tanks and similar systems in Ireland, devising an appropriate implementation strategy was far from easy. Nevertheless, the Irish EPA was able to identify situations where concentrations of domestic waste systems posed particular problems, such as areas of proximity to freshwater pearl mussels or places where the geology increased the likelihood of contamination of surface waters or groundwater. The agency then addressed the compliance problem, beginning with multi-level public education about the need for precautions, the need to register the systems, and techniques for achieving safety. It was then able to target inspections for unregistered sites in higher risk areas, while also making use of geographic information systems and proxies for contamination, such as downstream water quality, to identify violators. ${ }^{46}$

This episode illustrates the potential for supranational organizations to influence local policy. It also highlights the role that the expert community can play in transmitting innovative policy approaches across national boundaries.

These articles by no means exhaust the possible ways in which policy developments can span national boundaries outside the framework of traditional international law. At the very least, however, they testify to the significance of these mechanisms and the need for further research into their operations.

\section{CONCLUSION}

The articles in this issue provide a rich set of perspectives on the general problem of promoting transnational improvements in environmental policy. They discuss a diverse set of mechanisms, on a spectrum ranging from the formal dispute resolution of the ICJ to forms of international lawmaking such as treaty negotiation to informal cross-border linkages by NGOs.

These mechanisms cannot guarantee positive results, either alone or in combination. Sources of resistance are diverse and include not only concrete obstacles and conflicting economic interests but also cultural and ideological divisions. There is a strong need to better understand the mechanisms and how they can respond to

45 Baldwin, Black \& O'Leary, n. 41 above.

46

Ibid. 
various resisting forces. This is, in part, a purely intellectual need on behalf of scholars. However, it is also a pressing practical need if we are to make progress in addressing key environmental problems. Obviously, no single set of articles can resolve these formidable difficulties, but the articles in this issue of TEL make significant contributions to this enterprise.

\author{
Editors-in-Chief \\ Thijs Etty \\ Veerle Heyvaert \\ Editors \\ Cinnamon Carlarne \\ Dan Farber \\ Jolene Lin \\ Joanne Scott
}

